九州大学学術情報リポジトリ

Kyushu University Institutional Repository

Sudies on the flying-fishes of the Amakusa Islands. : Part 1. Faunal discussion with the life-historical notes

Tsukahara, Hiroshi

Fisheries Laboratry, Department of Agriculture, Kyusyu University

https://doi.org/10.5109/22682

出版情報: 九州大学大学院農学研究院紀要. 11 (2)，pp. 165-189，1959-08. Kyushu University バージョン：

権利関係 : 
Journal of the Faculty of Agriculture, Kyūsh̄̄ University, Vol. 11, No. 2

August 31, 1959

Studies on the flying-fishes of the Amakusa Islands.

Part 1. Faunal discussion with the life-historical notes ${ }^{1,2)}$

Hircshi Tsukahara

The present paper is a descriptive list of the flying-fishes collected off the western coast of the Amakusa Islands, Kyushu Province, Japan. Several species of the flying-fish have considerable importance economically to the fishery in this region. This fishery operates mainlys by the gill net during the summer. During my recent studies on the economical fishes of the Amakusa Islands, I began to be interested in the habits and the life histories of flying-fishes and attempted to survey the flyingfish fauna in this region. Imai (1955) recorded nineteen species in the larval stage off the southern waters of Kyushu Province, but in Amakusa region a knowledge about the flying-fish fauna was not sufficient. It will be a pleasure to me if the present study can add something to the knowledge of geographical distribution and the life histories of these Aying-fishes.

This report includes thirteen species; five adult forms of the genera Parexocoetus, Cypselurus and Prognichthys, and thirteen immature forms of the genera Oxyporhamphus, Parexocoetus, Exocoetus, Cypselurus, Prognichthys and Hirundichthys collected by myself in 1955.

The adult form was taken by the gill net and the young, juvenile and larval forms were captured mainly by a dip net with the aid of a flood light at night. I found these methods were useful especially for collecting the flying-fishes in the various stages. Besides, collection of the juvenile was made by a dip net from their favorite hiding

1) Contribution from the Fisheries Laboratory, Faculty of Agriculture, Kyushu University.

2) Contribution from the Amakusa Marine Biological Laboratory, Faculty of Science, Kyushu University. No. 99, 
places in the floating sea-weeds. The work has been carried out in the Amakusa Marine Biological Laboratory, Faculty of Science, Kyushu University. The Amakusa Islands are situated in the warmer temperate region, and the western coast of the outer main island opens to the East China Sea. The southern tropical fishes are brought up by Tsushima Warm Current, so that these fish fauna are rich.

Here, I wish to express my sincere thanks to Prof. Keitaro Uchida and Prof. Hiroaki Aikawa, Laboratory of Fisheries, Kyushu University, for their guidance. I also extend my thanks to Assist. Prof. Sadahiko Imai, Faculty of Fisheries, Kagoshima University for many valuable suggestions, and to Assist. Tsukasa Shiokawa and the other staff of the Amakusa Marine Biological Laboratory for their assistance in collections and technical procedures.

The list of species described is as follows;

\section{Scientific Name}

1. Oxyporhamphus micropterus micropterus

(Cuvier et Valenciennes)

2. Parexocoetus mento mento (Valenciennes)

3. Parexocoetus brachypterus brachypterus (Richardson)

4. Exocoetus monocirrhus (Richardson)

5. Cypselurus heterurus döderleini (Steindacher)

6. Cypselurus katoptron (Bleeker)

7. Cypselurus opisthopus hiraii Abe

8. Cypselurus naresii (Günther)

9. Cypselurus starksi Abe

10. Cypselurus poecilopterus (Cuvier et Valenciennes)

11. Prognichthys agoo (Temminck et Schlegel)

12. Prognichthys seali Abe

13. Hirundichthys oxycephalus (Bleeker)
Common Name

Sayori-tobiuo

Bashō-tobiuo

Tsumari-tobiuo

Hagoromo-tobiuo

Tsukushi-tobiuo

Sannoji-damashi

Hoso-tobi

Uchida-tobiuo

Ariake-tobiuo

Aya-tobiuo

Tobiuo

Daruma-tobiuo

Hosoao-tobi

\section{Oxyporhamphus micropterus micropterus (Cuvier et Valenciennes)}

The specimens from this district are all immature forms and I have nine specimens, ranging from $50 \mathrm{~mm}$. up to $80 \mathrm{~mm}$. in fork length. These specimens were taken in July and August.

The body of the juvenile is elongated, compressed and the lower jaw produced as those in the halfbeaks, Hemiramphidae, and the lower lobe of caudal fin is more prolonged than the upper. The pectoral and ventral fins are short (Figs. 1, 2).

The ray counts are: Dorsal 14, Anal 14, Pectoral 12, Ventral 6.

The coloration of the body in life is bright silvery and the part of trunk is bright bluish. They were attracted to a flood light at 


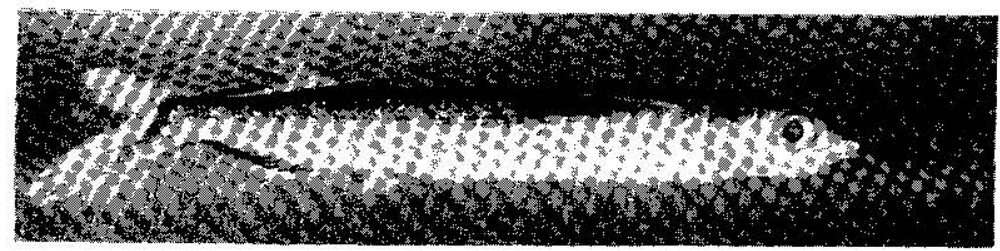

Fig. 1. Juvenile of Oxyporhamphus micropterus micropterus. $\times 1$

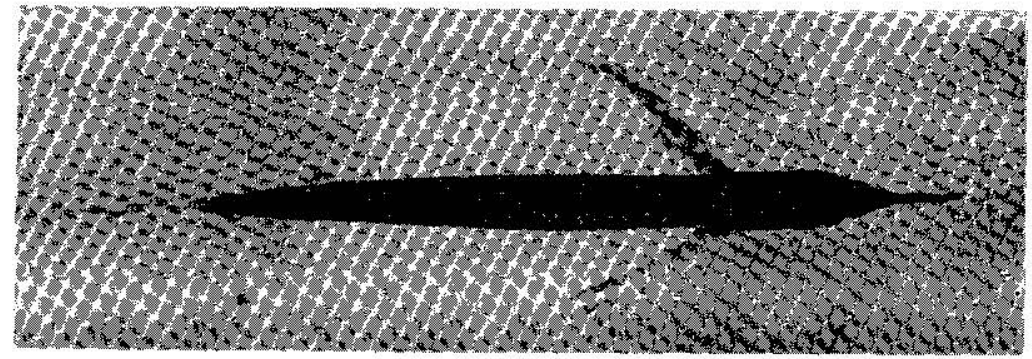

Fig. 2. Dorsal view of juvenile. $\times 1$

night and captured by a dip net when they lay motionless close to the water surface. They occasionally made short, sporadic flights, similar to that of Hemirhamphidae.

\section{Parexocoetus mento mento (Valenciennes)}

Maturing adults were collected in the period from May to October and the spawned-out were observed in this region and my material shows the series of developmental stages. This species is the smallest in size in adult among the flying-fishes taken from this region, the largest being $130 \mathrm{~mm}$. in the female and $123 \mathrm{~mm}$. in the male in fork length, so far as I have examined. They feed entirely on planktonic organisms, mostly copepods.

The shape of the body in adult stage is rather long and compressed; Fig. 3 shows the general appearance of the species. The dorsal fin is remarkably high and the pectoral fins are oblong and of moderate length. The ventral fins are rather short and situated somewhat far forward on the body.

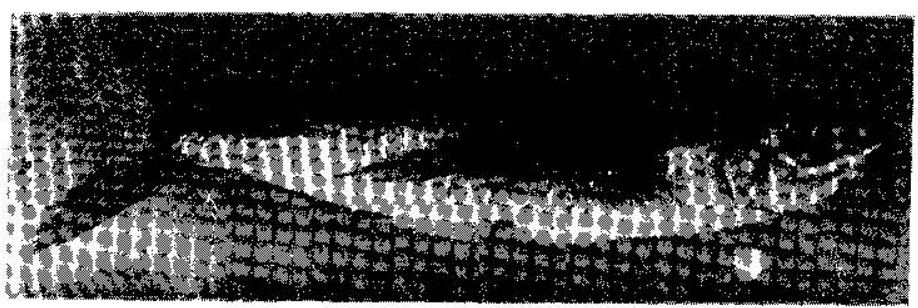

Fig. 3. Adult of Parexocoetus mento mento, Fork length $12 \mathrm{~cm}$. 
The ray counts are: Dorsal 9-10, Anal 11-12, Pectoral 12, Ventral 6.

The coloration of the body in life is dark bluish above and silvery white below and all faint yellowish. The dorsal fin is quite black excluding the base. The upper part of the pectoral is faint grayish and the ventral fins are hyaline.

The spawning season occurs from May to September and the peak is in June and July. The eggs were stripped and inseminated with the milt from the male. The embryonic development was observed and the hatched larvae were reared in the aquarium. The egg is spherical, $1.75-1.78 \mathrm{~mm}$. in diameters, with about 20 long entangling tendrils distributed over the whole surface (Fig. 4). The yolk is transparent and the oil-globule absent.

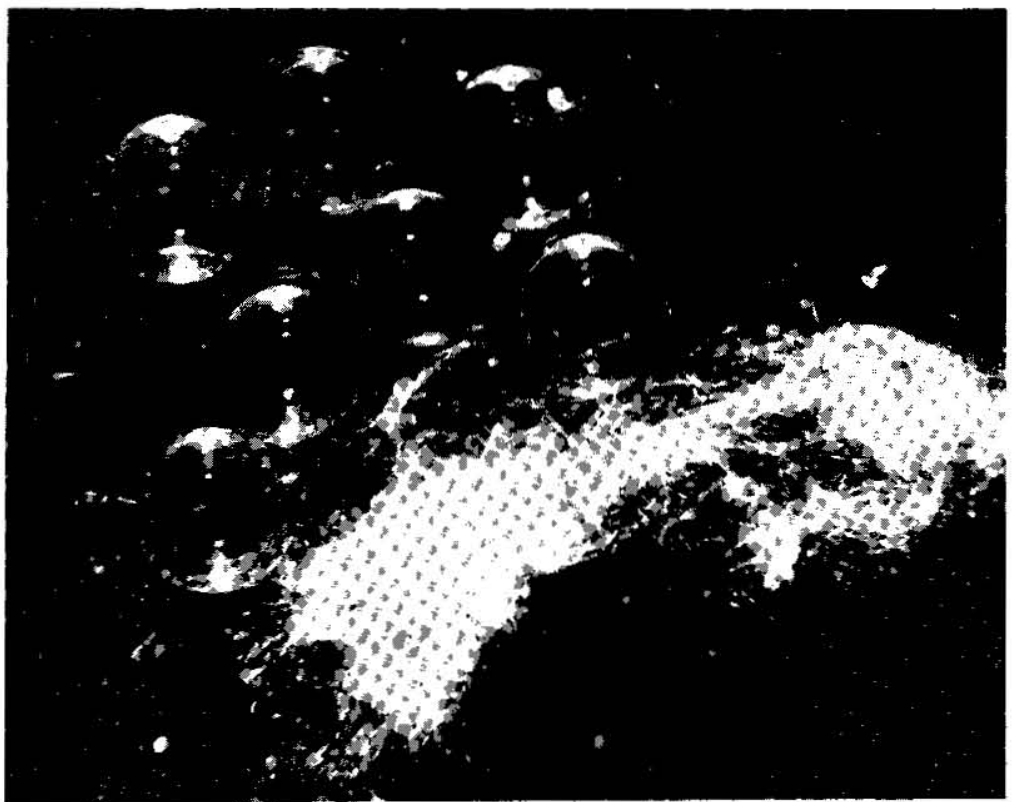

Fig. 4. Eggs of Parexocoatus mento mento. $\times \mathrm{ca} .10$

The number of cggs in the ovary is presumed to be from about 1,000 to 2,000. The spawning seems to take place at once from the sunset to the next morning. It requires about 10 days at $21^{\circ}-25^{\circ} \mathrm{C}$. water temperature to hatch out. The hatching-out takes place in several hours after the sunset. The newly hatched larvae were $4.5-5.2 \mathrm{~mm}$. in total length. In the larval stages the body is a little more robust and the fin rays have definitely developed, except the pectoral fins. The coloration of the body is dark brownish above and bright yellow brownish below. The ventral fins are dark greenish. Immature forms 
from $10 \mathrm{~mm}$. up to $48 \mathrm{~mm}$. in fork length were captured numerously by a dip net under a night light. The juvenile appeared from early July to late October (Fig. 5).

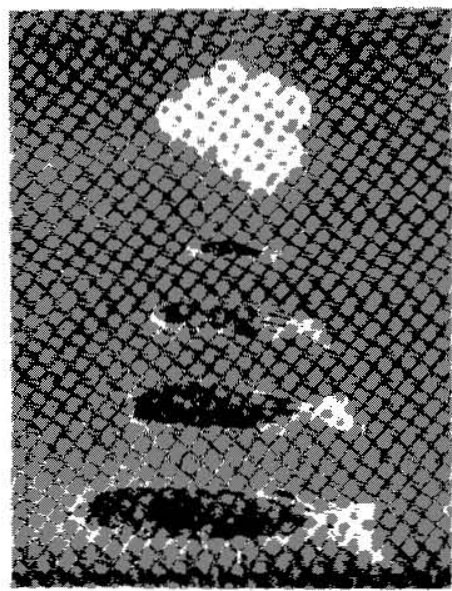

Fig. 5. Eggs, larvae and juveniles of Parexocoetus mento mento. $\times$ ca. 2

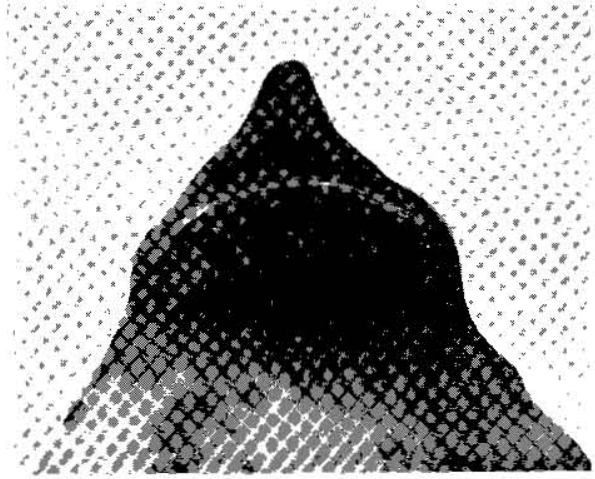

Fig. 6. Dorsal view, of prolonged lower jaw. $\times 20$

In the juvenile stages, the elevation of dorsal fin increases and the dorsal fin is wholly black, except near the base. The ventral fins are large and almost brownish. The characteristics of pigmentation are the three rows of melanophores which are situated along the dorsal, anal bases and the lateral portion of posterior body. The barbel of the lower jaw is absent, but the lower jaw produced a little as in the saury, Scombresocidae (Fig. 6). These small fishes spread out the four "wings" and could leap into the air for a distance of a foot. In the specimens longer than $25 \mathrm{~mm}$. in fork length, the shape of body agrees with the adult form and is dark bluish above and silvery white below (Figs. 7, 8).

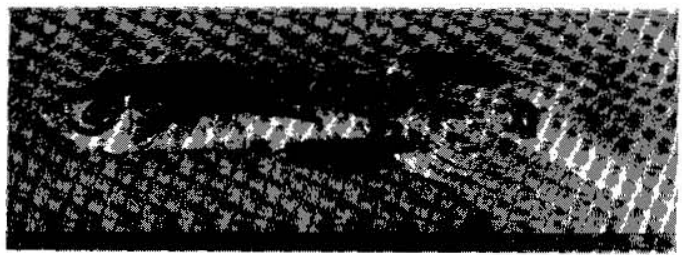

Fig. 7. Young of Parexocoetus mento mento. $\times 2$

The growth is so rapid that the fishes almost become matured in one year. They spawned at the end of their first year and most of them seem to die after spawning. Maturity is reached at the size of about $98 \mathrm{~mm}$, in fork length in the male and $119 \mathrm{~mm}$. in the female. 
The young shows a tendency to leave this region in winter migrating towards the southern waters.

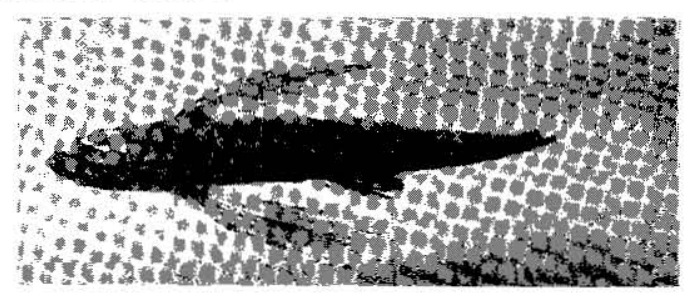

Fig. 8. Dorsal view of young. $\times 2$

Parexocoetus brachypteras brachypterus (Richardson)

The specimens are all small in size, and ranges from 25 to 60 $\mathrm{mm}$. in fork length are taken in July. Imai (1955) has recorded the capture of adults off the southern region of Kyushu, but I could not collect the adults in Amakusa region.

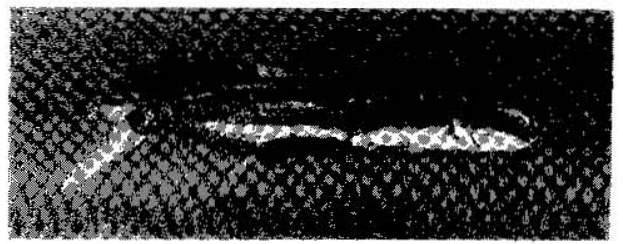

Fig. 9. Juvenile of Parexocoetus brachypterus brachypterus. $\times I$

The body of a juvenile is rather long and compressed. The midmost ray of the dorsal fin is greatly prolonged, thus giving a remarkably high shape to the fin. The pectoral fins are rather short. The ventral fins are relatively long, although those of the adult rather short (Figs. 9, 10). During earlier stages, the lower jaw has a pair of short, black barbel (Fig. i1).

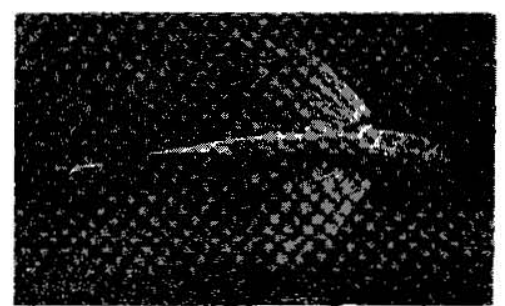

Fig. 10. Dorsal view of juvenile. $\times 1$

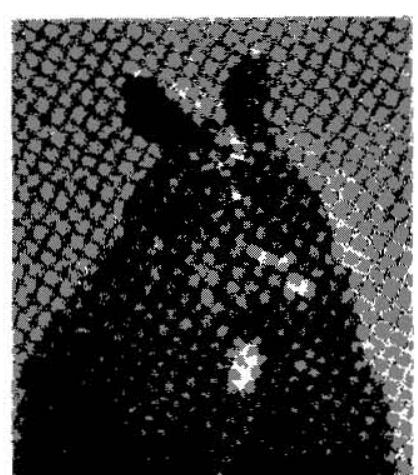

Fig. 11. Dorsal view of barbel of lower jaw. $\times 10$ 
The ray counts are: Dorsal 13, Anal 13, Pectoral 12, Ventral 6.

The coloration of the body is dark above and silvery white below and a dark band of pigment across the eye extends to the middle part of the caudal peduncle. The dorsal fin is quite black and the anal fin is black, except in the proximal part, which is hyaline. The pectoral and ventral fins are grayish.

Two juvenile forms of Parexocoetus, $P$. brachypterus brachypterus and $P$. mento menlo, were found in this region and in the same season. During the juvenile stage, this species is darker in the color of body and higher in dorsal fin than $P$. mento mento and has a pair of barbel under the lower jaw, but the latter is absent.

\section{Exocoetus monocirrhus (Richardson)}

The present material is all juvenile, with a maximum fork length of $58 \mathrm{~mm}$. which was taken in July and August, and adults were not collected. They were captured by a dip net when they lay motionless under a night light with the pectoral fins spread out and the barbel of lower jaw prolonged anteriorly.

The bcdy of a juvenile is short and high, and the head is elevated steeply behind the eyes. The pectoral fins are very long and the ventral fins are short and anteriorly situated (Figs. 12, 13). An

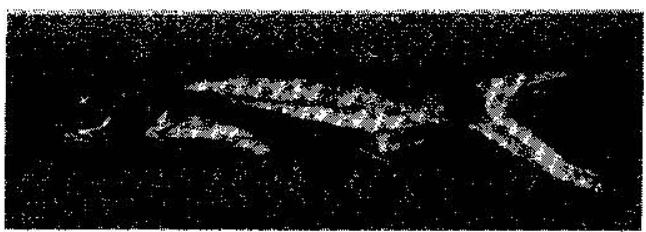

Fig. 12. Juvenile of Exocoetus monocirrhus. $\times 1$.

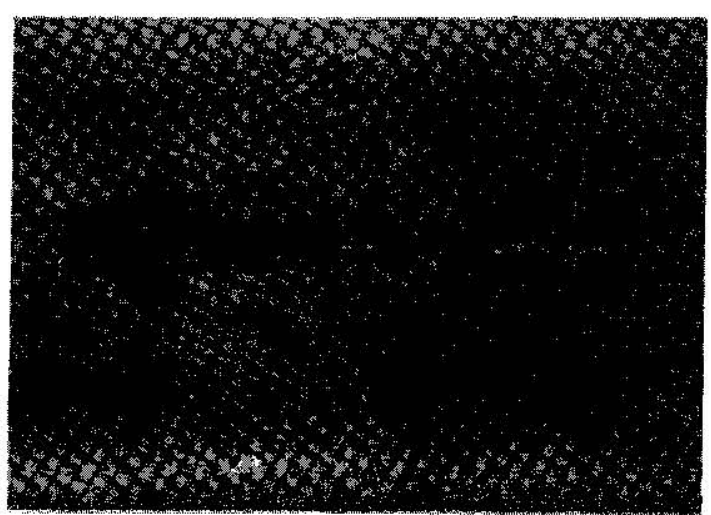

Fig. 13. Dorsal view of juvenile. $\times 1$ 
unpaired barbel of the lower jaw is rather long and slightly expanded laterally with the tip being roundish and quite black (Fig. 14).

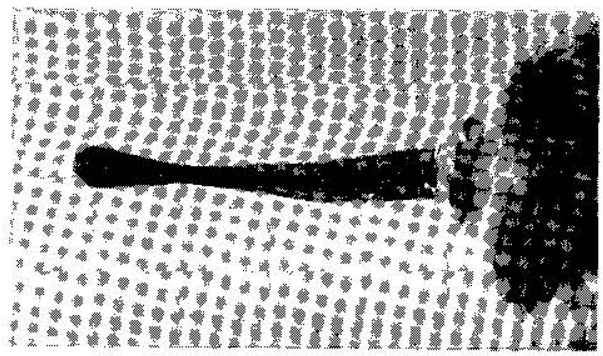

Fig. 14. Dorsal view of barbel of lower jaw. $\times 5$

The ray counts are: Dorsal 13, Anal 13, Pectoral 15, Ventral 6.

The coloration of the body in life is brownish blue above and silvery white below, with three obscure vertical black bars on the sides. The pectoral fins are faint grayish with a black vertical band on the middle part, a black line runs along the posterior margin with black parts on the base (Fig. 12). The ventral fins are hyaline. The dorsal fin is nearly transparent, with an obscure black bar. Sometimes these small fishes would glide in the air for a distance of at least 10 feet before striking the water again under a night light.

\section{Cypselurus heterurus döderleini (Steindachner)}

This is the larger form and is of economical importance among the flying-fishes in this region. I have a large series of developmental stages.

The body of the adult is rather slender and the belly is angular along the ventral edge; Fig. 15 shows the general appearance of the species. The pectoral fins are long and reach past rear of dorsal base. The tip of the ventral fins reaches the base of the 9th anal fin-ray. The origin of the ana! fin is far behind that of the dorsal fin.

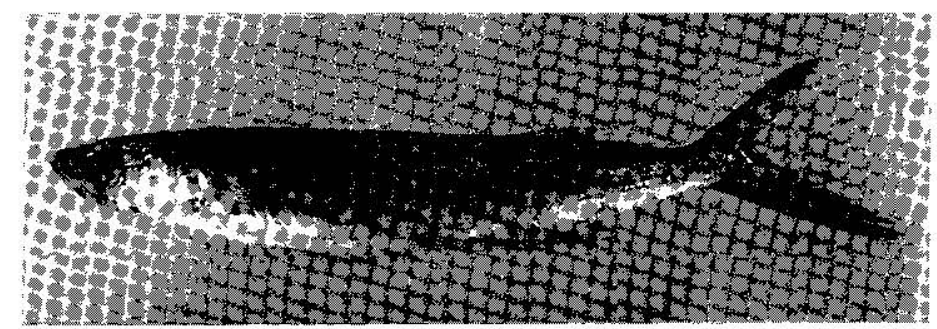

Fig. 15. Aduit of Cypselurus heterurus cölerleini. Fork length $28 \mathrm{~cm}$.

The Iray counts are: Dorsal $12-14$, Anal 9--11, Pectoral 15-17, Ventral 6. The number of vertebrae (including the urostyle) is $47^{--49}$. 
The coloration of the body in life is dark bluish above and silvery white below. The pectoral fins are faint greyish violet with the exception of the central part, margin and lower part being lighter. The dorsal, anal and ventral fins are greyish. They feed entirely on planktonic organisms, mostly copepods. The adult in this region is in spawning condition and the spawning takes place in May, June and July. The number of eggs carried by an adtult female varied from about 8,500 to 10,000 . The eggs were stripped and inseminated with milt from the male. The embryonic devclopment was observed and the hatched larvae were reared in the aquarium, fed with the nauplii of the brine shrimp.

The eggs are spherical, on the average $1.86 \mathrm{~mm}$. in diameter, having about 50 long tendrils attached uniformly over the whole surface (Fig. 16). The hatching-out takes place in about 14 days at $20^{\circ}-22^{\circ} \mathrm{C}$. water temperature and in several hours after the sunset. The newly hatched larvae were about $6.3 \mathrm{~mm}$. in total length and swam in the water surface and darted about very actively in the aquarium. In the

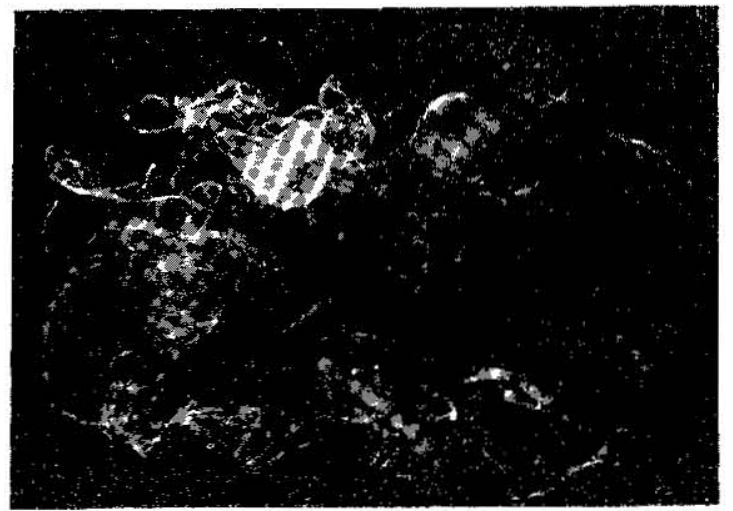

Fig. 16. Eggs of Cypselurus ineterurus döuerleini. х ca. 5

larval stages, the shape of the body is a littie robust, and with the most striking variation in color pattern, as a!l white, cream yellow, range yeliow, brown and dark brown. The pectoral and ventral fins are relatively large and the color is red brownish. In 25 days it attains about $14 \mathrm{~mm}$. in total length and the caudal fin had begun to differenciate, lower lobe becoming longer. At this stage any disturbance in the water of the aquarium would cause these small fish to jump out of the water and glide for a short distance in the air.

Immature forms, from 14 to $110 \mathrm{~mm}$. in fork length were captured numerously by a dip net under a night light. They swam sluggishly about near the light, so that they were very easily captured by a dip 


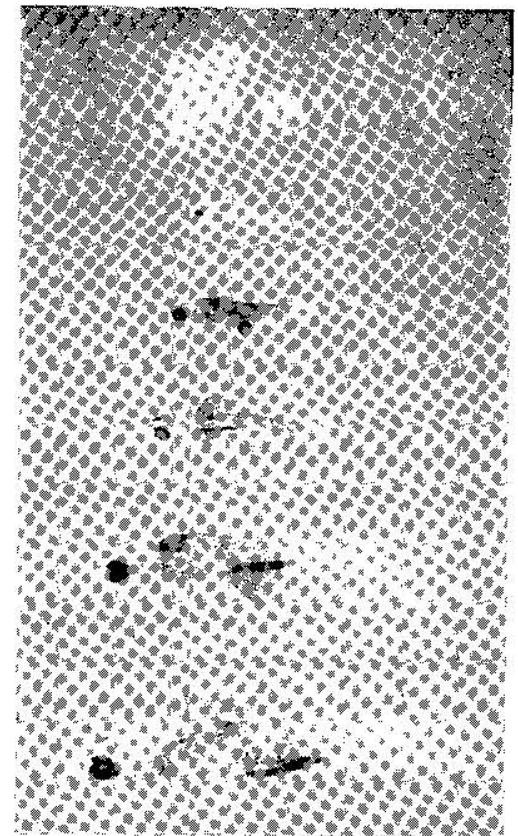

Fig. 17. Eggs, larvae and juveniles of Cypselurus heterurus diderleini. $\times$ ca. 2 net. In the juvenile stages, the body is slender and the coloration is bright orange yellow and has five vertical black bands on the sides.

These bands are continuous with the black parts of the dorsal and anal fins (Figs. 17, 18, 19). The juvenile larger than $15 \mathrm{~mm}$. in fork length has a yellow paired barbel with the outer black flap, which is retained in the young fish, $110 \mathrm{~mm}$. in fork length (Fig. 20).

In the young fish longer than $150 \mathrm{~mm}$. in fork length, the shape and the color of the body nearly agree with the adult, although the middle part of the pectoral fin is pale (Fig. 21). These young fishes are of great importance in the western waters of Kyushu during October and November, and they migrate to the southern waters in winter.

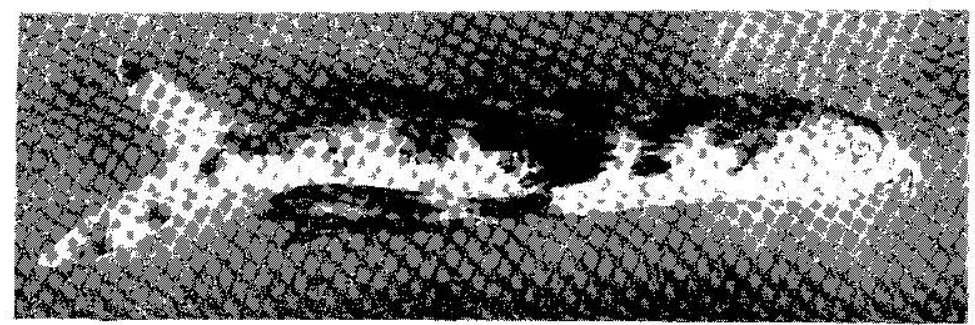

Fig. 18. Juvenile of Cypselurus heterurus doderleini. $\times 1$

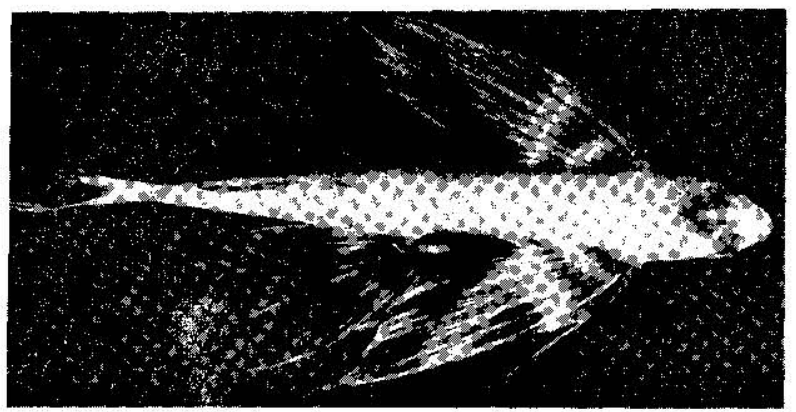

IFi. 19. Dorsal view of juvenile. $\times 1$ 
Growth is very rapid and in one month it attains about $20 \mathrm{~mm}$., in three months about $80 \mathrm{~mm}$. and in one full year $250-300 \mathrm{~mm}$. in fork length. Most fishes become matured and spawn at the end of the first year.

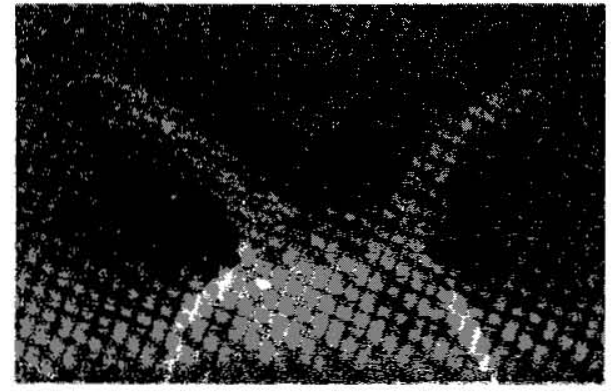

Fig. 20. Dorsal view of barbel of lower jaw. $\times 5$

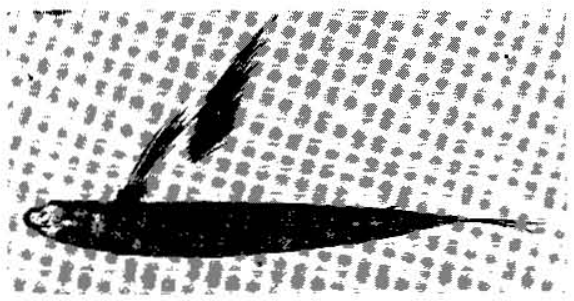

Fig. 21. Dorsal view of young. Fork length $18 \mathrm{cr}$.

\section{Cypselurus katoptron (Bjeeker)}

Those at hand are 6 specimens ranging from 35 to $110 \mathrm{~mm}$. in fork length, but the adult was not collected. These specimens were

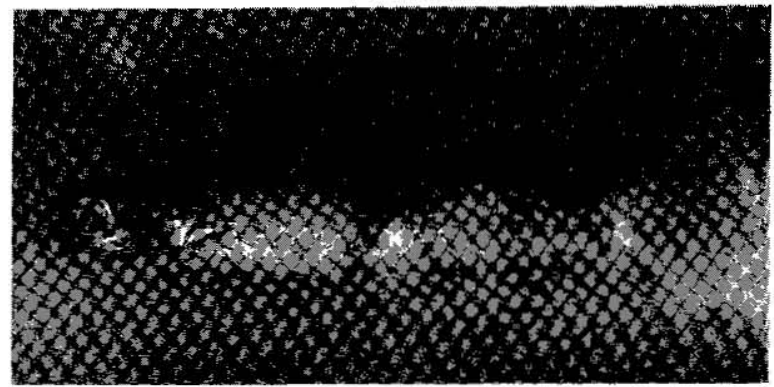

Fig. 22. Juvenile of Cypsehurus iatoptron. $\times 1.5$

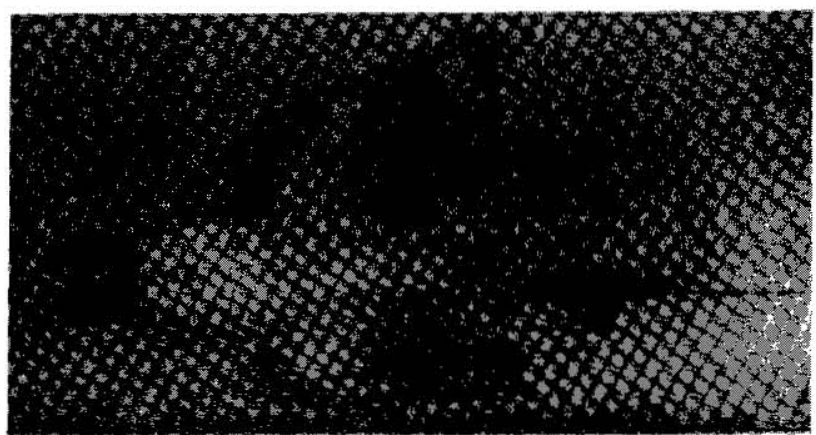

Fig. 23. Dorsal view of juvenile. $\times 1.5$ 
taken in July. They were attracted to a night light with the pectoral and ventral fins spread out and a paired barbel was held forward and slightly downward. The body of the juvenile is rather robust and the pectoral and ventral fins are large (Figs. 22, 23).

The ray counts are: Dorsal 14, Anal 10, Pectoral 15, Ventral 6. In the juvenile, the coloration of the body in life is silvery yellow, with three obscure vertical black bands on the sides. These three

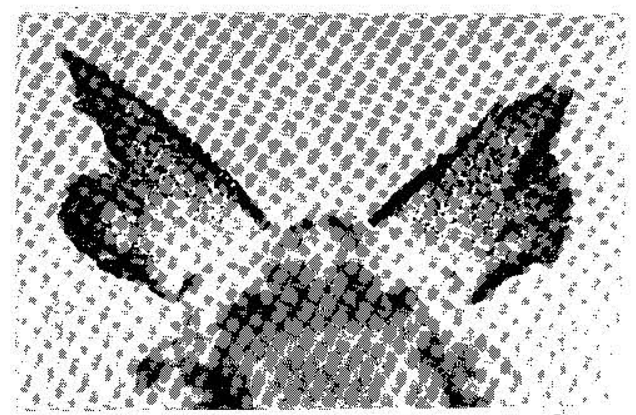

Fig. 24. Dorsal view of barbel of lower jaw. $\times 5$

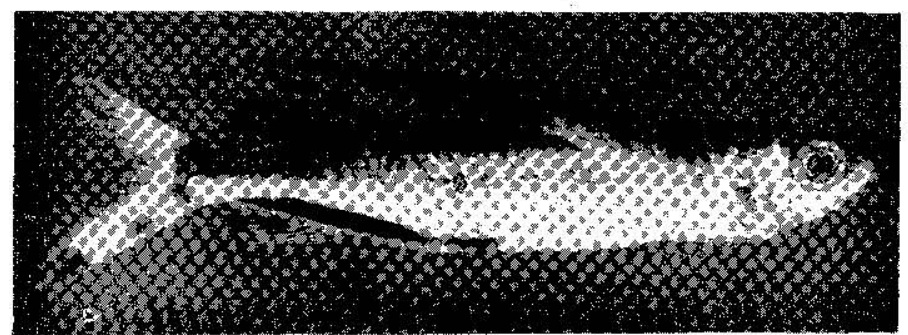

Fig. 25. Young of Cypselurus katoptron. $\quad \times 1$

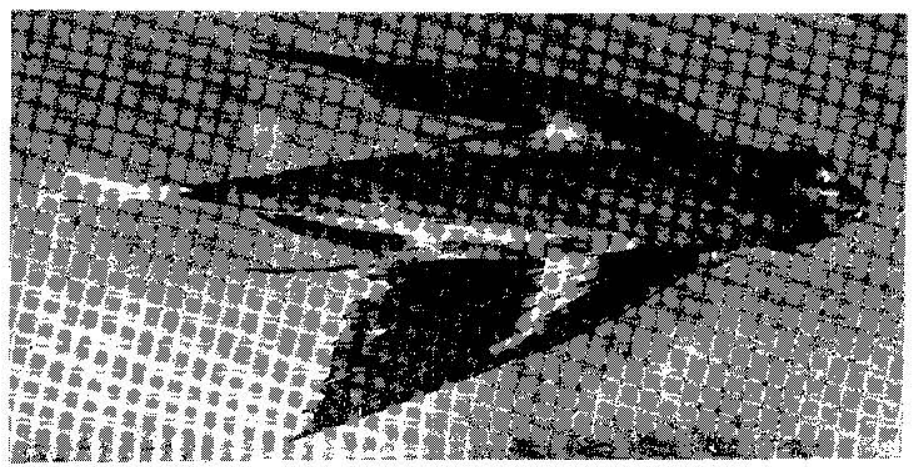

Fic. 26. 1)orsal view of young. $\times 1$

bands are continuous with the black parts of the dorsal and anal fins. The pectoral fins have a yellow part at its midmost part. During 
earlier stages the lower jaw has a pair of triangular yellow barbel with the margin black (Fig. 24). In the stages longer than $75 \mathrm{~mm}$. in fork length, the shape of body is slender and the coloration is black bluish above and silvery white below with the barbel being Iost (Figs. $25,26)$.

\section{Cypselurus opisthopus hiraii Abe}

This species is the most important economically among the flyingfishes in this region and I have a large series of material indicating the life history. The adult form is medium sized among the flyingfishes and the body is rather slender; Fig. 27 shows the general appearance of the species. The pectoral fins are long and the tip reaches at the middle of dorsal base.

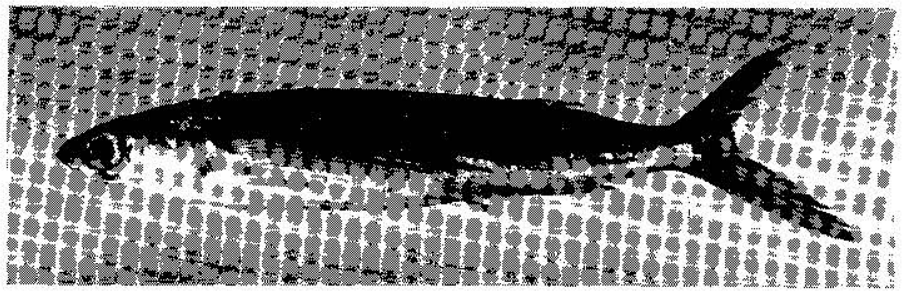

Fig. 27. Adult of Cypselurus opisthopus hiraii. Fork length $22 \mathrm{~cm}$.

The ray counts are: Dorsal 11--14, Anal 9-10, Pectoral 14-15, Ventral 6. The number of vertebrae (including urostyle) is $45-46$.

The coloration of the body is dark bluish above and silvery white below. The pectoral fins are greyish violet, except the lower part is transparent. The dorsal, anal and ventral fins are greyish. The adults that appeared in this region are in spawning condition and the spawning takes place in May, June and July. The number of the eggs carried out by an adult female varied from about 4,000 to 7,500 .

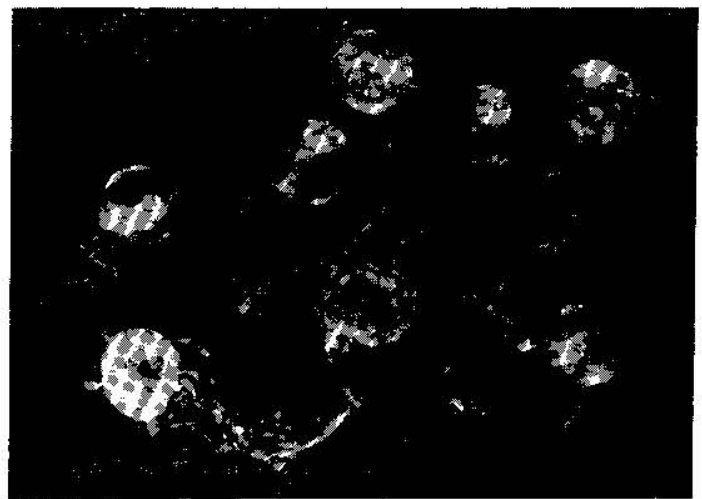

Fig. 28. Eggs of Cypselurus opisthopus hiraii. $\times \mathrm{ca}, 5$ 
The eggs are spherical on average $1.47 \mathrm{~mm}$. in diameter and have about 50 long tendrils attached uniformly over the whole surface (Fig. 28).

The eggs were stripped and inseminated with the milt from the male and the development was observed and the hatched larvae were reared in the aquarium, fed with the nauplii of the brine shrimp. The hatch-out takes place in about 14 days at $20^{\circ}-22^{\circ} \mathrm{C}$. water tempcrature and in several hours after the sunset. The newly hatched larvae were about $4.7 \mathrm{~mm}$. in total length.

Abe (1955) considercd that the natural hybrids between the present species and Cypselurus heterurus döderleini seem to occur infrequently, from the two points that the spawning season of both species agrees and intermediate forms sometimes occur in nature. I experimented on the hybrids between the present species and $C$. heterurus döderleini or $C$. starksi. The crossing was easily done on the mature egg and sperm, and the embryonic development was apparently normal, but the all hatched larvae died in the postlarval stage. I have not seen the intermediate form in nature during my studies.

In the larval stage, the body

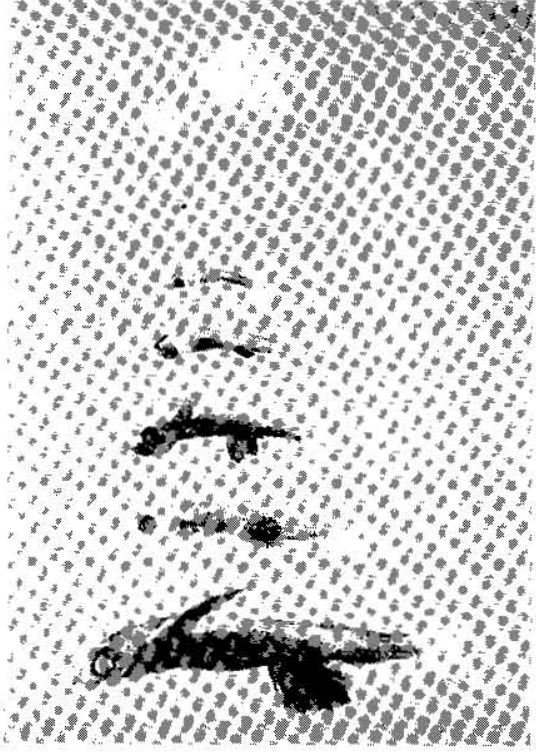

Fig. 29. Eggs, larvae and juveniles of Cypselurus opisthopus hiraii.

$x$ ca. 2 is rather slender and reveals the temporary variation of color from nearly white to dark brown. The pectoral and ventral fins are relatively large and brownish. They swam close to the surface of water with the pectoral and ventral fins widely spread and darted about very actively by the rapid movement of the caudal peduncle (Fig. 29). In 3 days, attaining about $7 \mathrm{~mm}$. in total length, they show a tendency to attach to the sea-weeds (Fig. 30). By the sudden disturbance in water, one-month old larva, about $20 \mathrm{~mm}$. in fork length, leapcd out beyond the fence of the aquarium of which $15 \mathrm{~cm}$. high above the water.

The juvenile forms, from 20 to $105 \mathrm{~mm}$. in fork length were captured numerously by a dip net under a night light. In the juvenile stages, the body is slender and the coloration is dark brownish above and black below. The juvenile longer than $12 \mathrm{~mm}$. in fork length, it has a black rounded barbel (Fig. 31). 


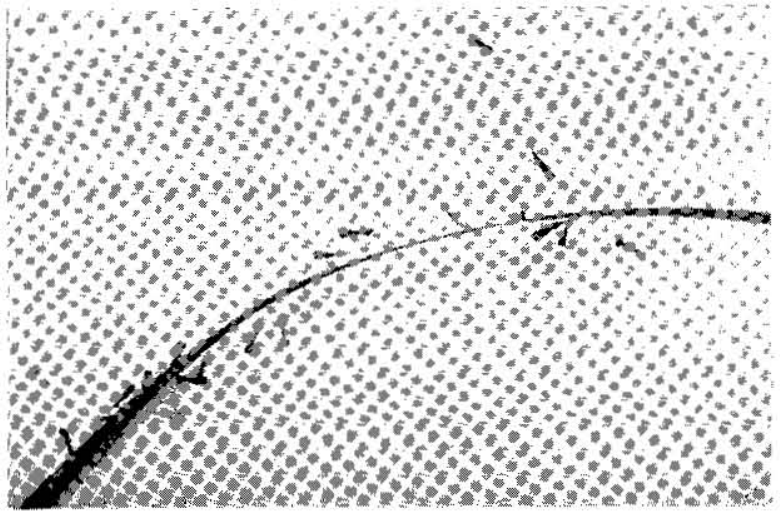

Fig. 30. Larvae attached to the sea-weed in aquarium. $\times 1$

In advanced stages, the coloration of the body is dark bluish above, silvery on side with a longitudinal black band, and black below. The pectoral fins are black, except the lower transparent part. The ventral fins are black (Figs. 32, 33). The young, longer than $100 \mathrm{~mm}$. in fork length, lacks the barbel on the lower jaw and the shapc of the body and the coloration agree with the adult form, dark bluish above, silvery white below.

The growth is very rapid and in a

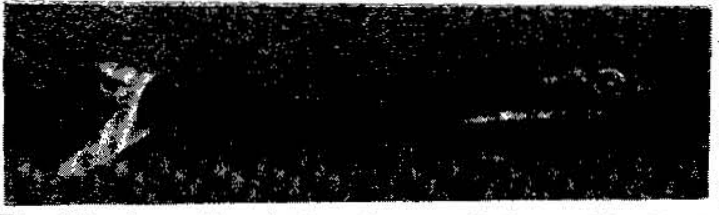

Fig. 32. Juvenile of Cypselurus opisthopus hiraii. $\times \mathrm{I}$

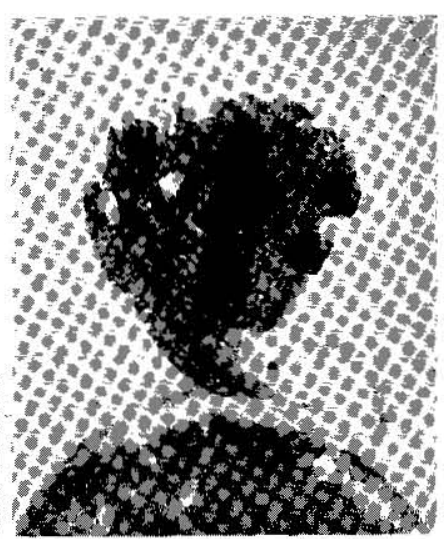

Fig. 31. Dorsal view of barbel of lower jaw. $\times 12$

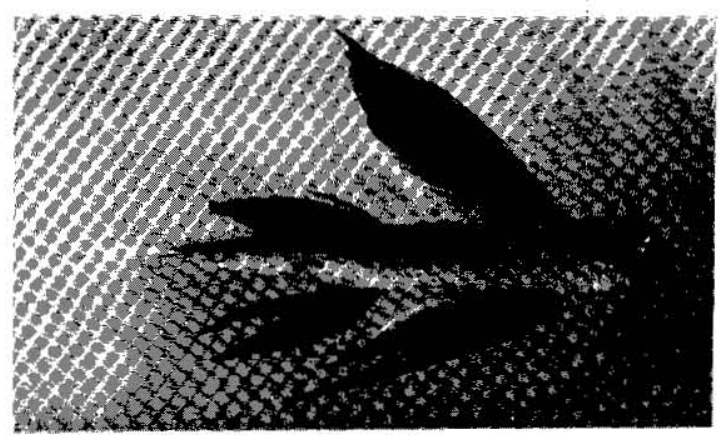

Fig. 33. Dorsal view of juvenile, $\times 1$ 
month it attains about $20 \mathrm{~mm}$., in three months $80 \mathrm{~mm}$. and in one full year $200-240 \mathrm{~mm}$. in fork length and the most of them seem to mature and spawn. These four or five month old fishes are important economically in the western waters of Kyushu during October and November, and then they show a tendency to leave there for the southern waters in winter.

\section{Cypselurus naresii (Günther)}

The present materials are all juvenile with a maximum fork length of $73 \mathrm{~mm}$. and were taken in July, and the adult was not collected. The general appearance in juvenile is similar to the juvenile of $C$. opisthopus hiraii, but is distinguished by the number of vertebrae and the barbel of lower jaw. The body of the juvenile is rather slender (Figs. 34, 35). The pectoral fins are large and the tip reached to the base of lower rudimentary caudal fin-ray.

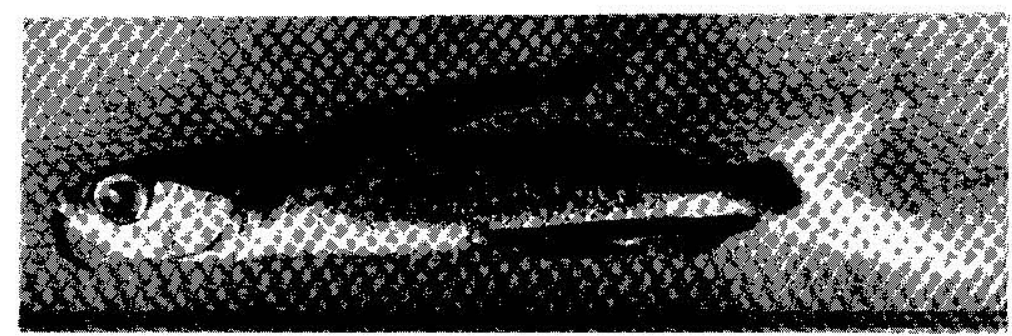

Fig. 34. Juvenile of : Cypselurus narasii. $\quad \times 1.2$

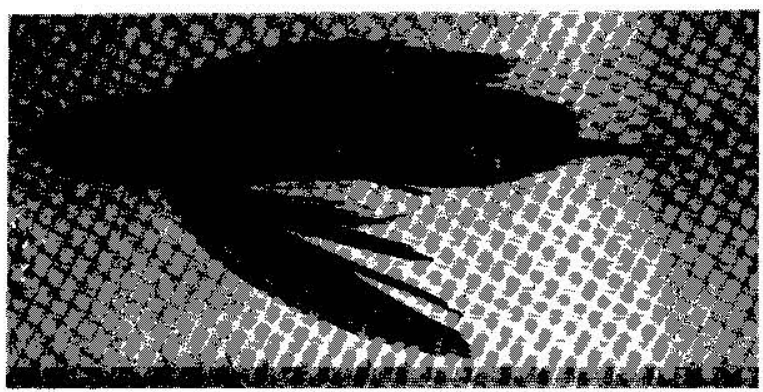

Fig. 35. Dorsal view of juvenile. $\times 1$

The ray counts are: Dorsal 12, Anal 10, Pectoral 15, Ventral 6. The number of vertebrae (including urostyle) is 42 .

The coloration of the body is dark bluish above, silvery white below and has a longitudinal black band on the side. The pectoral fins are black except the lower transparent part. The ventral fins are black. The lower jaw has a considerable long black barbel like a ribbon 
(Fig. 36). They were attracted to a light at night with the pectoral and ventral fins spread out and the barbel of lower jaw protruded anteriorly.

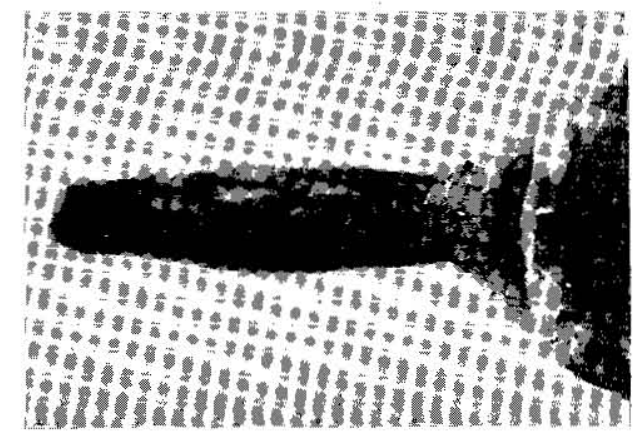

Fig. 36. Dorsal view of barbel of lower jaw. $\times 5$

\section{Cypselurus starksi Abe}

The present species is of economical importance among the flyingfishes in this region. I have a large series of materials indicating the life history.

The adult was captured from June to August. The adult form is rather robust and medium in size anong the flying-fishes with the snout rather blunt; Fig. 37 shows the general appearance. The pectoral fins are long and broad, and the tip reaches the posterior end of the dorsal base.

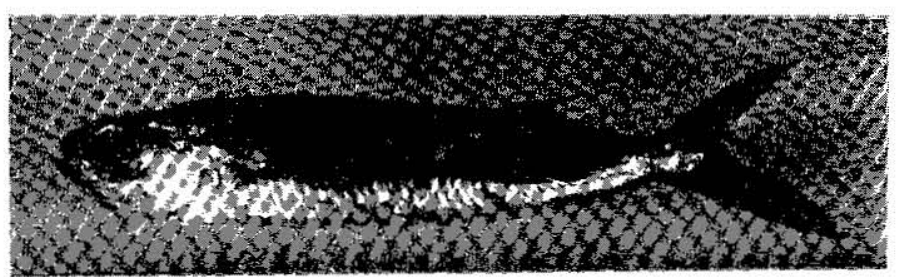

Fig. 37. Adult of Cypselurus starksi. Fork length $20 \mathrm{~cm}$.

The ray counts are: Dorsal 12-14, Anal 8 9, Pectoral 15-16, Ventral 6. The number of vertebrae (including urostyle) is $43-44$.

The coloration of the body is dark bluish above and silvery white below. The pectoral fins are bluish black and the lower part is transparent. The dorsal, anal and ventral fins are greyish.

The spawning season commences in early July and ends in August, and the spawning act seems to take place at once after the sunset till the next morning. The number of the eggs carried by one female 
varied from about 4,000 to 8,000 . The eggs were stripped and inseminated with milt from the male and the embryonic development were observed. The hatched larvac were rcared in the aquarium, fed with the nauplii of brine shrimp.

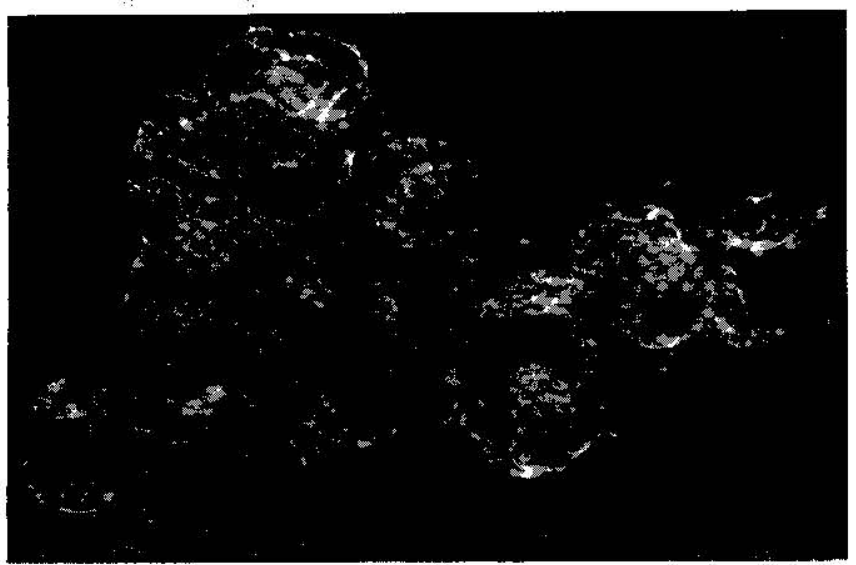

Fig. 38. Eggs of Cypselurus starksi. $\times$ ca. 7

The egg is spherical, on average $1.66 \mathrm{~mm}$. in diameter with about 5 ) long tendrils scattered over the whole surface (Fig. 38). The hatch-

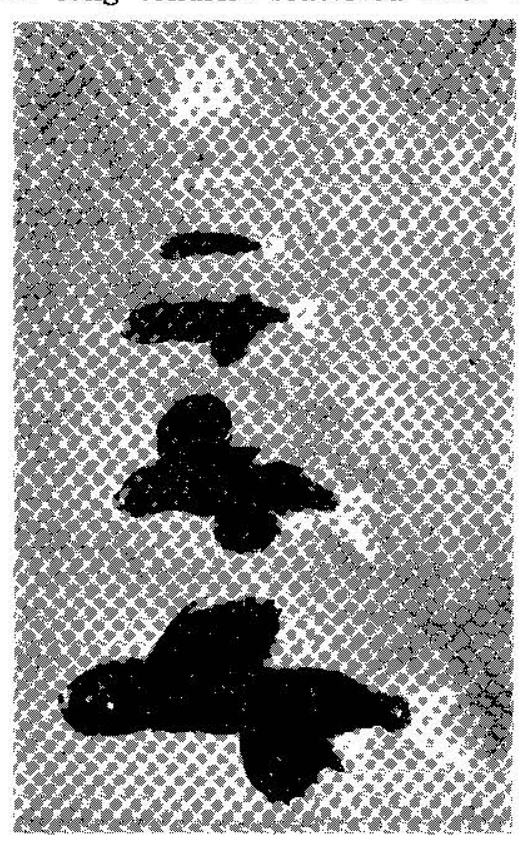

Fig. 39. Eggs, larvae and juveniles of Cypselurus starksi. $\times$ ca. 2 out takes place in about 6 days at $26^{\circ}-28^{\circ} \mathrm{C}$. water temperature and in several hours after the sunset.

In the larval stages the body is robust and the coloration varies considerably among the reared specimens and shows temporary change from yellow to dark red-brown in color pattern. The pectoral fins are \& greyish with the basal part slightly brownish and the ventral fin is almost dark except the marginal part. The prolarva is very heavily pigmented (Fig. 39). In one month, it attained about $17 \mathrm{~mm}$. in fork length and began to jump out of the water in the aquarium by a sudden disturbance.

Immature forms, from 23-98 $\mathrm{mm}$. in fork length, were captured numerously by a dip net under a night light. In the juvenile stages, 
the body is robust and in coloration the majority of them appear to be rather profusely dotted with black, although they are quite brownish. The fins are all well developed and the pectoral and ventral fins are dark bluish and the lower lobe of the caudal fin is elongated (Figs. 40,

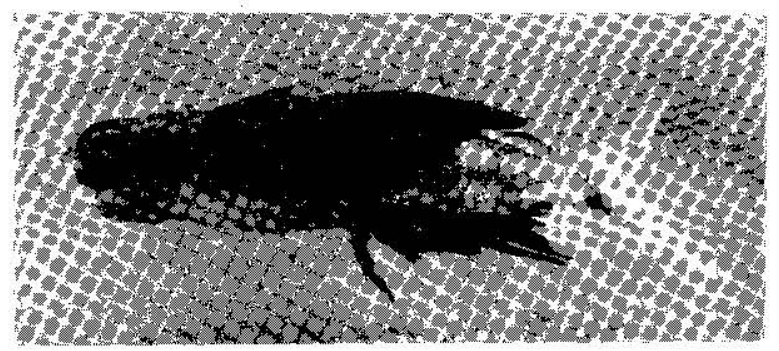

lig. 40. Juvenile of Cypselurus starksi. $\times 1$

41). These juveniles lack the barbel of the lower jaw. In the young fish longer than $150 \mathrm{~mm}$. in fork length, the body is very robust and the color agrees with the adult, but the ventral fins are black.

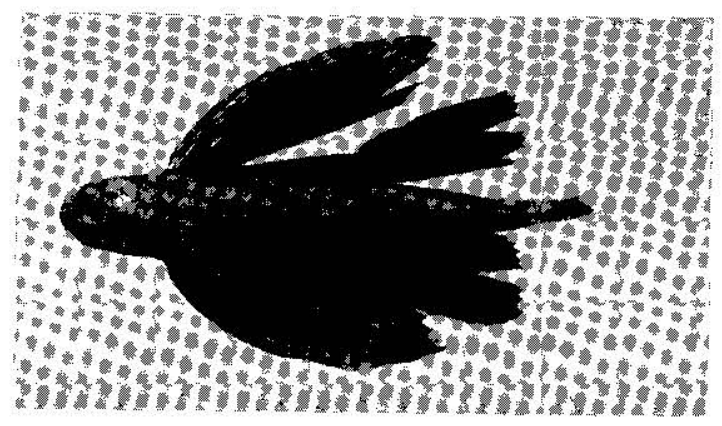

Fig. 41. Dorsal view of juvenile. $\times 1$

The advanced young, $120--150 \mathrm{~mm}$. in fork length, are economically important together with C. opisthopus hiraii and C. heterurus döderleini in the western waters of Kyushu during October and November. These young fishes probably migrate to the southern waters in winter. The growth is very rapid and in a month attains $18 \mathrm{~mm}$., in three months $80 \mathrm{~mm}$., in one full year $180-220 \mathrm{~mm}$. in fork length and the most fishes seem to mature and spawn.

\section{Cupselurus poecilopterus (Cuvier et Valenciennes)}

The present materials are two juvenile specimens being $60,70 \mathrm{~mm}$. in fork length, captured in August and September. The adult form 
was not collected. The spawning ground seems to be far southern waters from this region.

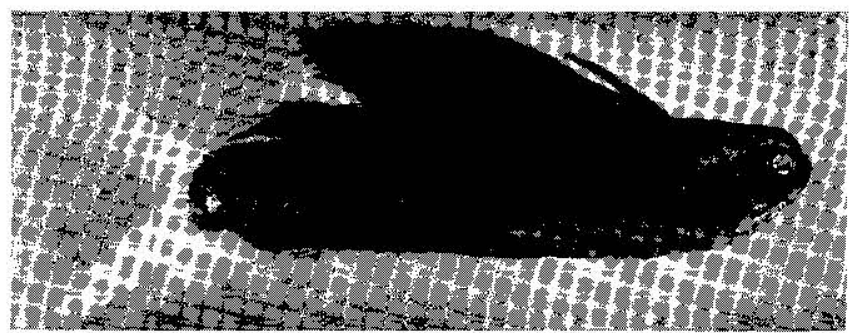

Fig. 42. Juvenile of Cypselurus poecilopterus, $\times 1$

In the juvenile, the body is very robust and the belly is angular along the ventral edge and the caudal peduncle is high (Figs. 42, 43). The eyes are large. The tip of pectoral fin reaches a little bcyond

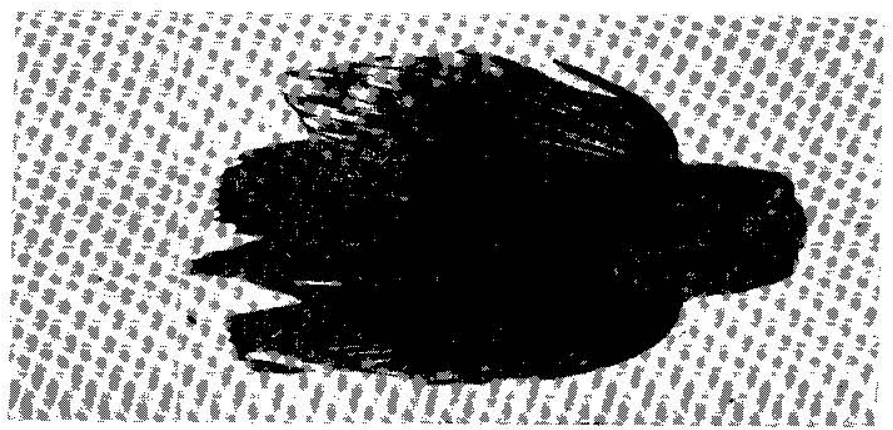

Fig. 43, Dorsal view of juvenile. $\times 1$

the base of last dorsal fin-ray. The ventral fins are large and the tip reaches to the base of the anteriormost rudimentary fin-ray of the lower lobe of caudal fin.

The ray counts are: Dorsal 12, Anal 8, Pectoral 15, Ventral 6.

The coloration of the body in life is brownish black. The color of pectoral and ventral fins are dark brownish with brownish black spots. The dorsal and anal fins are dark brownish. The barbel of the lower jaw is absent.

\section{Prognichthys agoo (Temminck et Schlegel)}

This species is economically important in Japan, but not abundant in this region. The adult appeared in September and the juvenile was captured in July.

The adult form is rather slender and the largest in size in this region; Fig. 44 shows the general appearance. The pectoral fins are 
long and the tip reaches a little beyond the base of dorsal fin. The tip of the ventral fin reaches the end of the last anal fin-ray. The origin of the anal fin is vertically below from the second to fourth of dorsal ray.

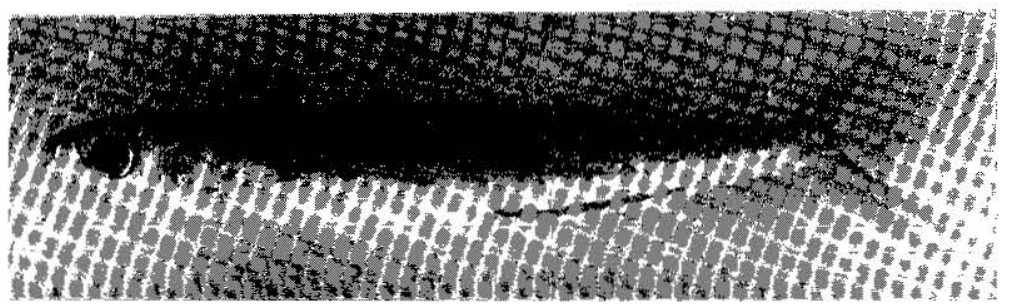

Fig. 44. Adult of Prognichthys agoo. Fork length $33 \mathrm{~cm}$.

The ray counts are: Dorsal 10 12, Anal 11, Pectoral 17, Ventral 6. The number of vertebrae (including urostyle) is 4648 .

The coloration of the body is black bluish above and silvery white below. The pectoral fins are blue greyish and the lower part is lighter. The dorsal and ventral fins are grey and the anal fin is transparent.

In the juvenile, the shape of body is slender (Figs. 45, 46). The coloration is brownish blue above and silvery white below. Small

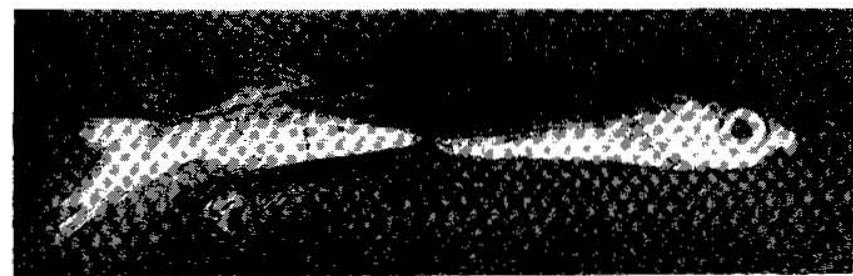

Fig. 45. Juvenile of Prognichthys agoo, $\times 1$

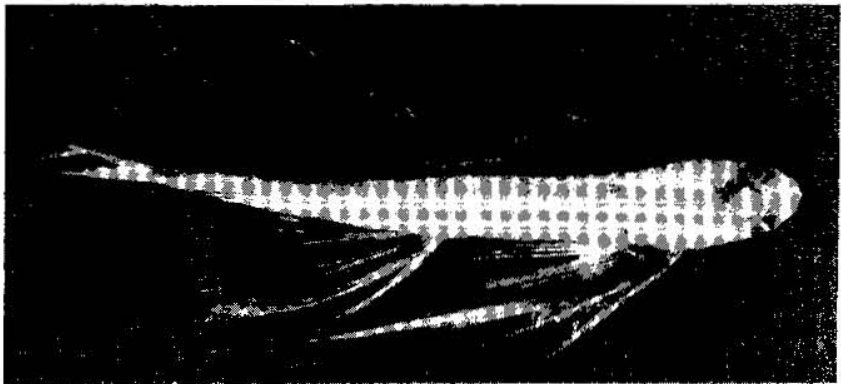

Fig. 46. Dorsal view of juvunile. $\times 1$

melanophores are scattered over the body with five obscure black bars on the belly. The shape of pectoral fin is peculiar and is faint blackish with a quite black line along the margin and the upper part is lighter. The ventral fins are broad and the color is faint black, the 
basal part paler. The lower jaw has a paired yellow barbel with black margin (Fig. 47).

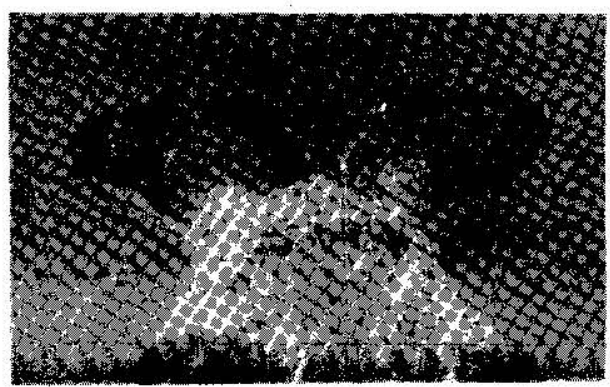

Fig. 47. -Dorsal view of barbel of lower jaw. $\times 5$

\section{Prognichthys seali Abe}

The present material is one juvenile specimen, $75 \mathrm{~mm}$. in fork length, captured in Juiy. Adult form was not collected. The body is very robust and the snout is short and the eyes are large (Figs. 48, 49). The posterior tip of pectoral fin reaches the base of last dorsal fin-ray. The tip of ventral fin reaches the origin of lower caudal fin-ray.

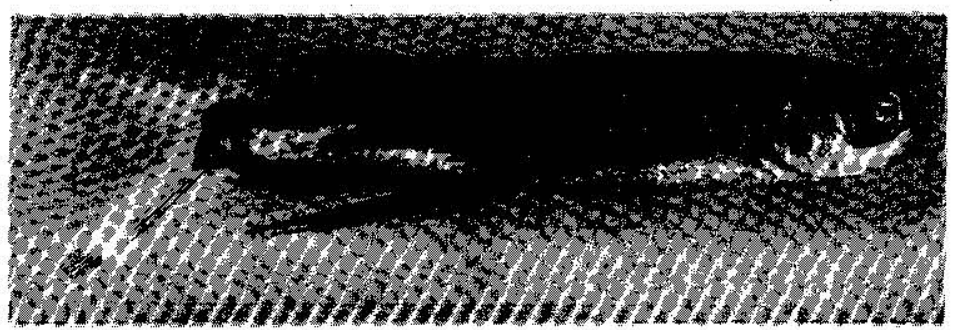

Fig. 48. Juvenile of Prognichthys seali. $\times 1$

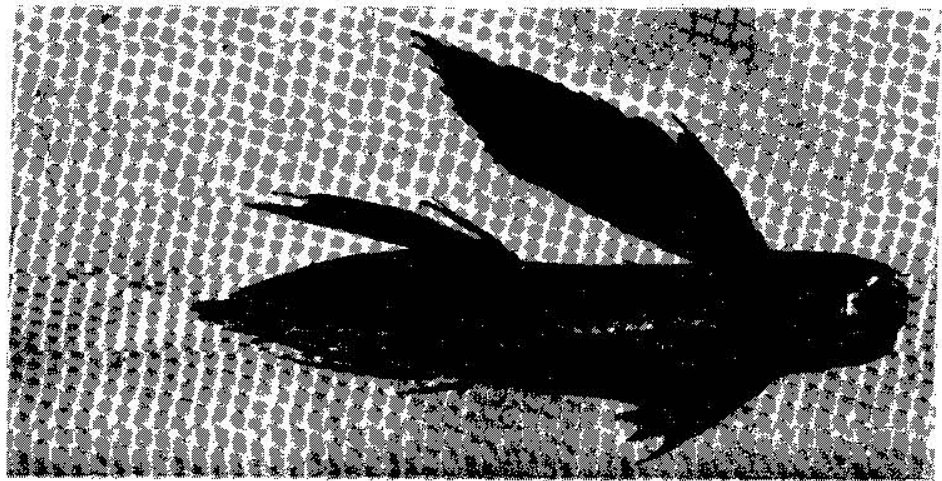

Fig. 49. Dorsal view of juvenile. $\times 1$ 
The ray counts are: Dorsal 10, Anal 9, Pectoral 19, Ventral 6.

The coloration of the body is bluish black above and silvery below. The pectoral fin is black with the postero-dorsal margin hyaline. The ventral fin is all black. The barbel of the lower jaw is absent.

\section{Hirundichthys oxycephalus (Bleeker)}

The present material is of post-larvae, juveniles and young, ranging from $12 \mathrm{~mm}$. up to $130 \mathrm{~mm}$. in fork length. Immature forms are abound in this region in July, August and September, but the adult was not collected.

In the specimen measured $130 \mathrm{~mm}$. in fork length, the shape of body is slender and similar to Cypselurus opisthopus hiraii, but differs from the latter in the position of the insertion of anal fin (Fig. 50). In the present species the anal fin is inserted nearly under the insertion of dorsal fin. The pectoral fins are long and reaches beyond the base of last dorsal finray. The tip of ventral fin reaches almost to the end of the anal base.

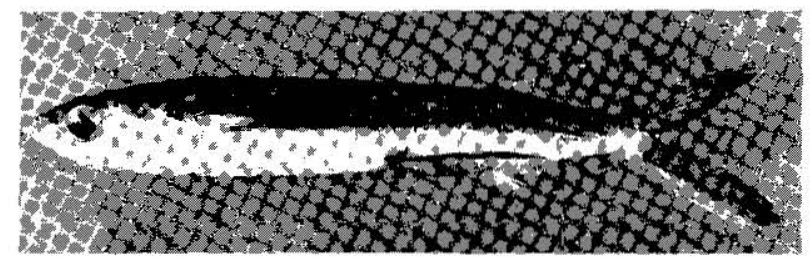

Fig. 50. Young of Hirundichthys oxycephalus. Fork length $13 \mathrm{~cm}$.

The ray counts are: Dorsal 10--11, Anal 11-12, Pectoral 1516 , Ventral 6. The number of vertebrae (including urostyle) is 45- 47 .

The coloration of the body is dark bluish above and silvery white

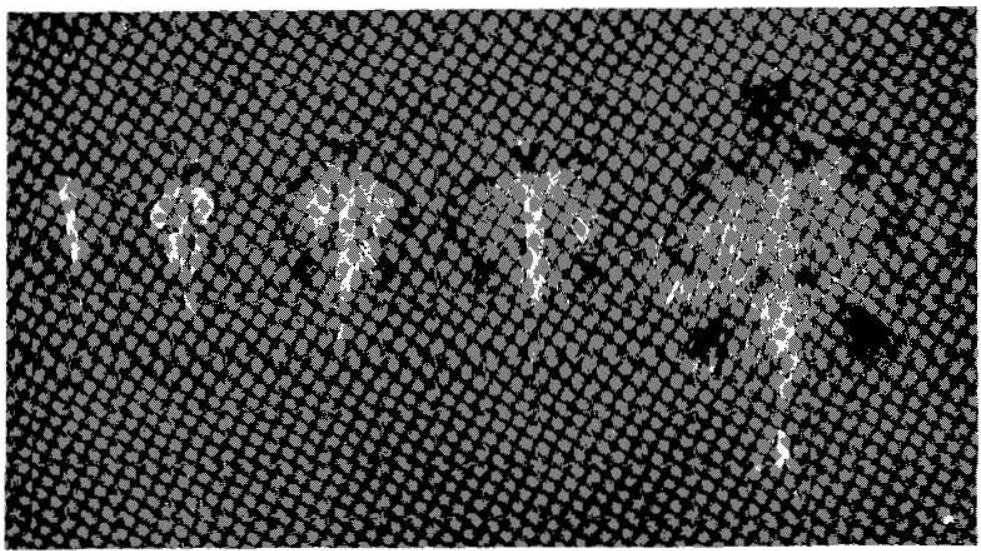

Fig. 51 Dorsal view of larvae and juvenile of Hiruntichthys oxyczphalus. $\times 1$ 
below. The pectoral fins are greyish purple, lower part transparent. The ventral fins are mostly transparent, the dorsal side being dark. The dorsal and anal fins are mostly transparent.

In the larval stages, the body is slender and the color is white with the melanophores scattered over the body. The pectoral and ventral fins are roundish with the margin black (Fig. 51). In the advanced form, the appearance of pectoral and ventral fins are shown in Figs. 52, 53. The pectorals have two black cross-bands which extend from the upper part to lower, and the basal part and the outer margin are black.

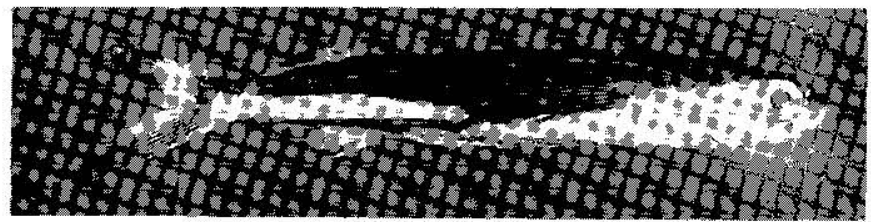

Fig. 52. Juvenile of Hirundichthys oxycephalus. $\times 1$

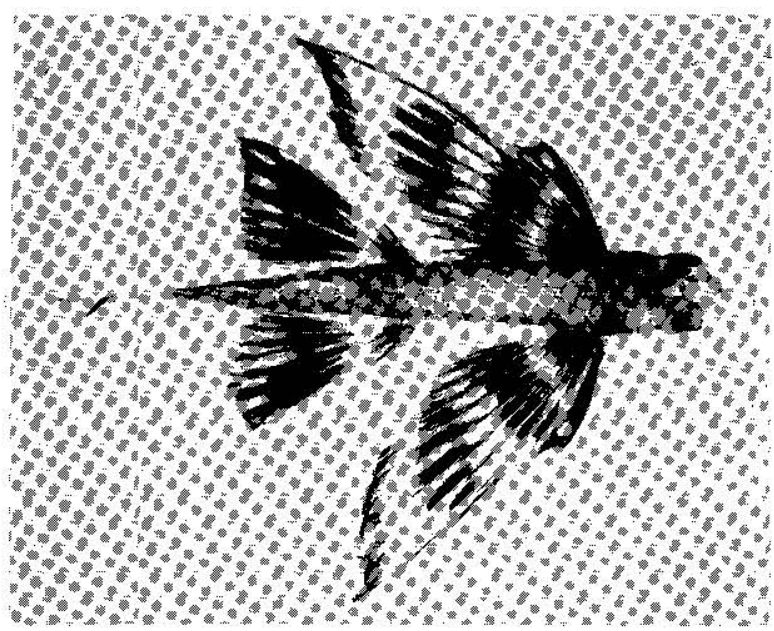

Fig. 53. Dorsal view of juvenile. $\times 1$

In the young fish the ventral fins are relatively long, having a broad black cross-band, and the basal part and the outer margin black. The dorsal fin has a black patch in the central part. The anal fin is clear. The barbel of the lower jaw is absent. They were attracted to a flood light at night and were swimming close to the surface and skipping or sailing through the air for some distance. Young specimens are economically important off the western coast of Kyushu, being caught in October and November together with the young of Cypselurus species. 


\section{LITERATURE}

1. Abe, T., 1953-'56. Figures and descriptions of the fishes of Japan. Vols. $49-52$.

2. $\quad \cdots$, 1955. On a new Pacific flying-fish, Prognichthys seali, retaining five unbranched fin-ray above in the pectoral throughout life. Records of Oceanographic Works in Japan. Vol. 2, No. 1.

3. Imai, S., 1950. On the young stages of flying fish as the natural food for bonito. (in Japanese). Memoirs of the Faculty of Fisheries, Kagoshima University. Voi. 1, No. 1.

4. $\quad-$, 1952. On a Japanese flying-fish and its juvenile of the genus Prognichthys Breder. (in Japanese). Ditto. Vol. 2, No. 1.

5. - - 1954. On two flying-fishes of the genus Hirundichthys Breder and their juveniles from Japan. (in Japanese). Ditto. Vol. 3, No. 2.

6. -- -- 1955. The juvenile of the fiying-fishes from the southern waters of Kyushu. (in Japanese). Tsushima Danryu Kaihatsu Chōsa Kenkyu Hōkoku. No. 2.

7. Ueno, M. and Nakahara, K., 1955. On the development of eggs: and rearing of larvae of a flying fish, Cypselurus starksi. (in Japanese). Science Bulletin of the Faculty of Agriculture, Kyushu University. Vol. 15, No. 1.

Fisheries Laboratory,

Faculty of Agriculture,

Kyushu University 